\title{
Correlation and Path Coefficient Analyses of Grain Yield and Yield Components in Two-Rowed of Barley (Hordeum vulgare convar. distichon) Varieties
}

\author{
Emine BUDAKLI CARPICI, Necmettin CELIK \\ Uludag University, Faculty of Agriculture, Department of Field Crops, Gorukle Campus, 16059 Bursa, Turkey; ebudakli@uludag.edu.tr
}

\begin{abstract}
This research sought to determine the correlations between grain yield and yield components and to measure the direct and indirect effects of yield components on grain yield in barley by using correlation coefficient and path analysis methods, respectively. This research was conducted with ten varieties of two-rowed barley under the ecological conditions of the coastal zone of northwest Turkey during the years 2003-2004. Agronomic traits such as grain yield, plant height, spike length, kernel number per spike, kernel weight per spike, spike number per $\mathrm{m}^{2}$, harvest index and 1000-kernel weight were determined. The data from two years were combined. Correlation analyses indicated that the grain yield was positively and significantly associated with all the yield components except 1000-kernel weight. The highest correlation coefficients were found between grain yield and kernel number per spike $(\mathrm{r}=+0.406)$, and between grain yield and harvest index $(r=+0.474)$. Results of path analyses indicated that harvest index had the greatest direct effect $(+0.7716)$ on grain yield followed by spike number per $\mathrm{m}^{2}(+0.3359)$ and kernel number per spike $(+0.2081)$. Percentages of their direct effect were $71.97 \%$, $48.47 \%$ and $28.22 \%$, respectively. On the other hand, most of the indirect effects of yield components on grain yield were found to be significant and positive. Because of the significant effects of the harvest index, spike number per $\mathrm{m}^{2}$ and kernel number per spike on grain yield, they may be regarded as criteria for barley improvement and breeding programs.
\end{abstract}

Keywords: barley, correlation, grain yield, path analysis, yield components

\section{Introduction}

Barley (Hordeum vulgare L.) is a common cereal used as food and as a feed crop. Barley is grown in nearly all the cultivated areas of the world. In Turkey, it is an important cereal crop, ranked second after wheat both in acreage and in production. For this reason and because of the need for new varieties, many studies aimed at creating improved, new genotypes have recently been conducted. A considerable number of grain production studies on barley include statistical correlations between agronomic and morphological characteristics and grain yield. Although these correlations are helpful in determining the principal components influencing final grain yield, they provide an incomplete representation of the relative importance of direct and indirect influences on the individual factors involved (Garcia del Moral et al., 1991). This generalization applies particularly to cereals. In cereals, yield components appear consecutively during the growing season, and they may compensate for each other's effects. It is known that the grain yield in cereals is determined by certain interrelated yield components. To identify the dimension of the effect of each yield component on grain yield is of importance for use in defining selection criteria for improving new varieties. Path coefficient and correlation analyses are used widely in many crop species by plant breeders to define the nature of complex interrelationships among yield components and to identify the sources of variation in yield. Knowledge derived in this way can be used to develop selection criteria to improve grain yield in relation to agricultural practices (Board et al., 1997; Finne et al., 2000; Gravois and McNew, 1993; Samonte et al., 1998; Sinebo, 2002).

A number of barley researchers sought to explain the relations of yield-related components by using path coefficient analysis (Dofing and Knight, 1994; Grafius, 1964; Garcia Del Moral et al., 1991; Hamid and Grafius, 1978; Puri et al., 1982). These researchers and others obtained results that included some discrepancies. Some studies reported that grain yield was determined by three yield components, e.g., spike number per $\mathrm{m}^{2}$, kernel number per spike and kernel weight per spike (Grafius, 1964). Some studies concluded that spike number per $\mathrm{m}^{2}$ was the primary determinant of grain yield in barley (Dofing and Knight, 1994). On the other hand, Singh et al. (1987) found that grain yield in barley was significantly correlated with plant height and spike length and that these two components had high positive direct effects on yield.

\section{Materials and methods}

This experiment was conducted during 2003-2004 in the coastal zone of northwest Turkey $\left(40^{\circ} 11^{\prime}\right.$ North, $29^{\circ}$ 04' East), at the Agricultural Research and Experiment 
Station of the Agriculture Faculty, Uludag University (Turkey). Ten varieties of two-rowed barley were used as genetic materials. The experimental soil was clay loam, nonsaline, poor in lime and organic matter, rich in potassium and had a neutral $\mathrm{pH}$. Average temperature, relative humidity and precipitation of growing seasons were, respectively, $10.5^{\circ} \mathrm{C}, 67.0 \%$ and $461.5 \mathrm{~mm}$ in 2003 , and $11.1^{\circ} \mathrm{C}, 68.1 \%$ and $555.7 \mathrm{~mm}$ in 2004 . The values of temperature, relative humidity and precipitation in 2003 were lower than normal. In 2004, temperature and precipitation had nearly normal values, but relative humidity was lower than normal.

The experiment was carried out using a split-plot design with three replications. The varieties studied were 'Angora', 'Balkan-96', 'Bilgi-91', 'Bornova-92', 'Cumhuriyet-50', 'Çildir-02', 'Kalayci-97', 'Sladoran', 'Süleymanbey-98' and 'Şerifehanım-98'. The second experimental treatment included four levels of nitrogen $(0,50,100$ and $150 \mathrm{~kg}$ $\left.\mathrm{ha}^{-1}\right)$. The main plots were allocated to varieties and the sub-plots to nitrogen levels. Sowing was done using a plot sowing machine. The area of sub-plot was $3 \times 1.2 \mathrm{~m}$. Eight rows were seeded at each sub-plot with $15 \mathrm{~cm}$ spacing. A hand-driven roller was used after sowing to pack down the soil for contact with the seeds. Meanwhile, one-third of each level of nitrogen fertilizer was applied at sowing and two-thirds at the jointing stage of plants. Ammonium nitrate of $26 \%$ was the source of nitrogen fertilizer. Measurements and observations for the parameters were accomplished on 15 plants chosen randomly from the mid-row of each plot. The parameters measured were plant height, spike length, kernel number per spike and kernel weight per spike, spike number per $\mathrm{m}^{2}$, harvest index, 1000-kernel weight and grain yield. Plant height and spike number per $\mathrm{m}^{2}$ were measured before harvest and the other parameters at or after harvest.

Data from both study years were combined. The simple phenotypic coefficients among all the measured components were first calculated by the Tarist statistical program and then separated into direct and indirect effects via path coefficient analysis as suggested by Anlarsal and Gulcan (1989), Sabanci (1996) and Turk and Celik (2006).

\section{Results and discussion}

Positive correlations appeared between grain yield and all the yield components except the 1000-kernel weight (Tab. 1). The positive and significant correlation coefficients ( $r$-values) between grain yield and the yield components such as plant height, spike length, kernel number per spike, kernel weight per spike, spike number per $\mathrm{m}^{2}$ and harvest index were $0.191^{* *}, 0.265^{* *}, 0.406^{* *}, 0.247^{* *}$, $0.361^{* *}$, and $0.474^{* *}$, respectively. Similar results for grain yield and plant height in barley were reported by other studies (Bhutta et al., 2005; Kisana et al., 1999; Samarrai et al., 1987). Akdeniz et al. (2004) observed positive and significant correlations between grain yield and yield compo- nents such as plant height, spike length and spike number per $\mathrm{m}^{2}$ but found negative and nonsignificant correlations between grain yield and kernel number per spike. Positive and significant correlations of grain yield with spike number per $\mathrm{m}^{2}$ and 1000-kernel weight were reported by Ataei (2006). In agreement with the results of this study, Bhutta et al. (2005) and Ilker (2006) found no significant correlation between grain yield and 1000-kernel weight. Most of the reciprocal relations among yield components were significantly positive. For instance, the correlations of plant height with spike length, kernel number per spike, kernel weight per spike, spike number per $\mathrm{m}^{2}$ and harvest index, and the correlations of spike length with kernel number per spike, kernel weight per spike and spike number per $\mathrm{m}^{2}$, as well as the correlations of kernel number per spike with kernel weight and spike number per $\mathrm{m}^{2}$ were all positive and significant. However, the analysis found some negative but significant correlations among some yield components, especially those involving harvest index. Indeed, the correlations of harvest index with spike length, kernel number per spike, kernel weight per spike and spike number per $\mathrm{m}^{2}$ were of this sort. On the other hand, the reciprocal relations of 1000-kernel weight with other yield components were nearly negative and/or nonsignificant, with some exceptions. The important exception was the correlation between 1000-kernel weight and kernel weight per spike, which was positive and significant (Tab. 1).

Path coefficient analysis was conducted by applying the correlation coefficients. This method partitioned the correlation coefficients into direct and indirect effects. The purpose of using path coefficient analysis in this study was to obtain further information about the interrelationships between the yield components studied and about their influence on grain yield.

The direct effects obtained from path coefficient analysis indicated that grain yields of barley cultivars were significantly and positively affected by yield components such as plant height, spike length, kernel number per spike, kernel weight per spike, spike number per $\mathrm{m}^{2}$ and harvest in$\operatorname{dex}(\mathrm{Tab} .2)$. These results indicate that an increase in any of these yield components causes some increase in grain yield. Similar results were reported by other researchers who conducted studies on different plant species and determined the direct effects of different yield components on grain yield: Khan et al. (1999); Moghaddam et al. (1998); Aycicek and Yildırım (2006); Turk et al. (2008) for plant height; Ataei (2006); Aycicek and Yildırım (2006); Mohammad et al. (2002); Narwal et al. (1999) for kernel number per spike; Aycicek and Yildırım (2006) for kernel weight per spike; Dofing and Knight (1994) for spike number per $\mathrm{m}^{2}$; Turk et al. (2008); Surek and Beser (2003); Surek et al. (1998); Albayrak and Tongel (2006) for harvest index. In terms of the priorities of the effects of yield components, the grain yield of the cultivars depended primarily upon harvest index and secondarily upon spike number per $\mathrm{m}^{2}$ in the research reported here. 
Tab. 1. Correlation coefficients among characters of varieties in two-rowed barley (averages of two years)

\begin{tabular}{|c|c|c|c|c|c|c|c|}
\hline Yield components & $\begin{array}{c}\text { 1000-kernel } \\
\text { weight }\end{array}$ & $\begin{array}{l}\text { Harvest } \\
\text { index }\end{array}$ & $\begin{array}{c}\text { Number } \\
\text { spike per } \mathrm{m}^{2}\end{array}$ & $\begin{array}{l}\text { Kernel weight } \\
\text { per spike }\end{array}$ & $\begin{array}{l}\text { Kernel number } \\
\text { per spike }\end{array}$ & $\begin{array}{l}\text { Spike } \\
\text { length }\end{array}$ & $\begin{array}{l}\text { Plant } \\
\text { height }\end{array}$ \\
\hline Grain yield & $-0.092^{\text {ns }}$ & $0.474^{* *}$ & $0.361^{* *}$ & $0.247^{* *}$ & $0.406^{* *}$ & $0.265^{* *}$ & $0.191^{* *}$ \\
\hline Plant height & $-0.038^{\mathrm{ns}}$ & $0.549^{* *}$ & $0.406^{* *}$ & $0.615^{* *}$ & $0.629^{* *}$ & $0.657^{* *}$ & - \\
\hline Spike length & $-0.040^{\mathrm{ns}}$ & $-0.313^{* *}$ & $0.188^{* *}$ & $0.736^{* *}$ & $0.776^{* *}$ & - & \\
\hline Kernel number per spike & $0.055^{\mathrm{ns}}$ & $-0.211^{* *}$ & $0.284^{* *}$ & $0.790^{* *}$ & - & & \\
\hline Kernel weight per spike & $0.303^{* *}$ & $-0.284^{* *}$ & $0.107^{\mathrm{ns}}$ & - & & & \\
\hline Number spike per $\mathrm{m}^{2}$ & $-0.150^{* *}$ & $-0.215^{* *}$ & - & & & & \\
\hline Harvest index & $-0.024^{\mathrm{ns}}$ & - & & & & & \\
\hline 1000-kernel weight & - & & & & & & \\
\hline
\end{tabular}

Tab. 2. Path analyses showing direct and indirect effects of yield components on grain yield (averages of two years)

\begin{tabular}{|c|c|c|c|c|c|c|c|c|}
\hline \multirow[b]{2}{*}{ Yield components } & \multirow[b]{2}{*}{$\begin{array}{l}\text { Direct } \\
\text { effects }\end{array}$} & \multicolumn{7}{|c|}{ Indirect Effects } \\
\hline & & $\begin{array}{l}\text { Plant } \\
\text { height }\end{array}$ & $\begin{array}{l}\text { Spike } \\
\text { length }\end{array}$ & $\begin{array}{c}\text { Kernel } \\
\text { number } \\
\text { per spike }\end{array}$ & $\begin{array}{c}\text { Kernel } \\
\text { weight per } \\
\text { spike }\end{array}$ & $\begin{array}{l}\text { Number } \\
\text { spike } \\
\text { per } \mathrm{m}^{2}\end{array}$ & $\begin{array}{c}\text { Harvest } \\
\text { index }\end{array}$ & $\begin{array}{c}\text { 1000-kernel } \\
\text { weight }\end{array}$ \\
\hline Plant height & $\begin{array}{c}0.2640 \\
(\mathbf{2 5 . 4 1 \%} \% *\end{array}$ & - & $\begin{array}{c}0.0271 \\
(\mathbf{2 . 6 1 \%})\end{array}$ & $\begin{array}{c}0.1310 \\
(\mathbf{1 2 . 6 1 \% )}\end{array}$ & $\begin{array}{c}0.0546 \\
(5.25 \%)\end{array}$ & $\begin{array}{c}0.1366 \\
(\mathbf{1 3 . 1 4 \% )}\end{array}$ & $\begin{array}{c}-0.4239 \\
(\mathbf{4 0 . 8 0 \% )}\end{array}$ & $\begin{array}{c}0.0019 \\
(\mathbf{0 . 1 8 \%})\end{array}$ \\
\hline Spike length & $\begin{array}{c}0.0413 \\
(\mathbf{5 . 5 2 \%})\end{array}$ & $\begin{array}{c}0.1734 \\
(\mathbf{2 3 . 1 8 \% )}\end{array}$ & 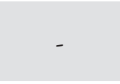 & $\begin{array}{c}0.1614 \\
(\mathbf{2 1 . 5 8 \% )}\end{array}$ & $\begin{array}{c}0.0653 \\
(8.73 \%)\end{array}$ & $\begin{array}{c}0.0631 \\
(8.44 \%)\end{array}$ & $\begin{array}{c}-0.2414 \\
(32.28 \%)\end{array}$ & $\begin{array}{c}0.0020 \\
(\mathbf{0 . 2 7 \%})\end{array}$ \\
\hline Kernel number per spike & $\begin{array}{c}0.2081 \\
(\mathbf{2 8 . 2 2 \%})\end{array}$ & $\begin{array}{c}0.1662 \\
(\mathbf{2 2 . 5 4 \% )}\end{array}$ & $\begin{array}{c}0.0320 \\
(\mathbf{4 . 3 5 \% )}\end{array}$ & - & $\begin{array}{c}0.0701 \\
(\mathbf{9 . 5 1 \% )}\end{array}$ & $\begin{array}{c}0.0954 \\
(\mathbf{1 2 . 9 5 \% )}\end{array}$ & $\begin{array}{c}-0.1626 \\
(\mathbf{2 2 . 0 5 \% )}\end{array}$ & $\begin{array}{c}-0.0028 \\
(\mathbf{0 . 3 8 \%})\end{array}$ \\
\hline Kernel weight per spike & $\begin{array}{c}0.0887 \\
(\mathbf{1 2 . 3 8 \% )}\end{array}$ & $\begin{array}{c}0.1624 \\
(22.65 \%)\end{array}$ & $\begin{array}{c}0.0304 \\
(\mathbf{4 . 2 4 \% )}\end{array}$ & $\begin{array}{c}0.1645 \\
(\mathbf{2 2 . 9 5 \% )}\end{array}$ & - & $\begin{array}{c}0.0360 \\
(\mathbf{5 . 0 3} \%)\end{array}$ & $\begin{array}{c}-0.2194 \\
(\mathbf{3 0 . 6 1 \% )}\end{array}$ & $\begin{array}{c}-0.0153 \\
(\mathbf{2 . 1 4 \% )}\end{array}$ \\
\hline Number spike per $\mathrm{m}^{2}$ & $\begin{array}{c}0.3359 \\
(\mathbf{4 8 . 4 7 \% )}\end{array}$ & $\begin{array}{c}0.1073 \\
(\mathbf{1 5 . 4 9 \% )}\end{array}$ & $\begin{array}{c}0.0078 \\
(\mathbf{1 . 1 2 \%})\end{array}$ & $0.0591(\mathbf{8 . 5 3 \% )}$ & $\begin{array}{c}0.0095 \\
(\mathbf{1 . 3 7 \%})\end{array}$ & - & $\begin{array}{c}-0.1659 \\
(\mathbf{2 3 . 9 3 \% )}\end{array}$ & $\begin{array}{c}0.0076 \\
(\mathbf{1 . 0 9 \% )}\end{array}$ \\
\hline Harvest index & $\begin{array}{c}0.7716 \\
(\mathbf{7 1 . 9 7 \% )}\end{array}$ & $\begin{array}{c}-0.1451 \\
(\mathbf{1 3 . 5 3 \% )}\end{array}$ & $\begin{array}{c}-0.0129 \\
(\mathbf{1 . 2 1 \% )}\end{array}$ & $\begin{array}{c}-0.0439 \\
(\mathbf{4 . 0 9 \% )}\end{array}$ & $\begin{array}{c}-0.0252 \\
(\mathbf{2 . 3 5 \% )}\end{array}$ & $\begin{array}{c}-0.0722 \\
(\mathbf{6 . 7 4 \% )}\end{array}$ & 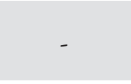 & $\begin{array}{c}0.0012 \\
(\mathbf{0 . 1 1 \% )}\end{array}$ \\
\hline 1000-kernel weight & $\begin{array}{c}-0.0505 \\
(\mathbf{2 9 . 8 1 \% )}\end{array}$ & $\begin{array}{c}-0.0100 \\
(\mathbf{5 . 8 9 \%})\end{array}$ & $\begin{array}{c}-0.0017 \\
(\mathbf{0 . 9 8 \% )}\end{array}$ & $0.0115(6.78 \%)$ & $\begin{array}{c}0.0269 \\
(\mathbf{1 5 . 9 0 \% )}\end{array}$ & $\begin{array}{c}-0.0504 \\
(\mathbf{2 9 . 7 9 \% )}\end{array}$ & $\begin{array}{c}-0.0184 \\
(\mathbf{1 0 . 8 5 \% )}\end{array}$ & - \\
\hline
\end{tabular}

${ }^{*}$ Numbers in parentheses refer to the percentages of path coefficients.

The indirect effects of yield components on grain yield on one another were generally positive with some exceptions. The most remarkable instance of the indirect effects of yield components involved the effect of harvest index on grain yield. Indeed, the indirect effects of harvest index on grain yield via yield components such as plant height, spike length, kernel number per spike, kernel weight per spike and spike number per $\mathrm{m}^{2}$ were significantly negative, indicating that an increase in one component caused a similar decrease in the other. Only a small positive indirect effect of harvest index on grain yield occurred. The effect was associated with an intercorrelation with 1000-kernel weight (Tab. 2).

This study has demonstrated that the grain yield of barley has significant and positive correlations with plant height, spike length, kernel number per spike, kernel weight per spike, spike number per $\mathrm{m}^{2}$ and harvest index. These relations mean that any increase in any one of the yield components causes some increase in grain yield. However, yield components have different effects on grain yield. These positive correlations between grain yield and yield components may be arranged, from higher to lower, as follows: 0.474 for harvest index, 0.406 for kernel number per spike, 0.361 for spike number per $\mathrm{m}^{2}, 0.265$ for spike length, 0.247 for kernel weight per spike and 0.191 for plant height. Finally, it is seen that harvest index, kernel number per spike and spike number per $\mathrm{m}^{2}$ have stronger effects on grain yield than do the other components. The direct effects of harvest index, spike number per $\mathrm{m}^{2}$ and kernel number per spike on grain yields of barley cultivars were more important than those of other yield components as indicated by path analysis. Their ranked percentages of direct effect were $71.97,48.47$ and $28.22 \%$, respectively. The results of this study indicate that harvest index, spike number per $\mathrm{m}^{2}$ and kernel number per spike may be used as selection criteria for new cultivars of two-rowed barley with higher grain yield.

\section{Acknowledgements}

This research work was supported by The Commission of Scientific Research Projects of Uludag University (Project No: 2003/87). The author is grateful to the Scientific Research Projects Unit of Uludag University for financial support. 


\section{References}

Akdeniz H, Keskin B, Yilmaz I, Oral E (2004). A Research on yield and yield components of some barley cultivars. Yüzüncü Yil Univ J Agric Sci 14(2):119-125.

Albayrak S, Tongel O (2006). Path analyses of yield and yieldrelated traits of common vetch (Vicia sativa L.) under different rainfall conditions. The J Agric Fac Ondokuz Mayis Univ 21:27-32.

Anlarsal AE, Gulcan H (1989). Determination of relations between yield and yield components in common vetch (Vicia sativa L.) by using path analysis under cukurova conditions. Turkish J Agric For 13:487-494.

Ataei M (2006). Path analysis of barley (Hordeum vulgare L.) yield. Ankara Univ Fac Agric J Agric Sci 12(3):227-232.

Aycicek M, Yildırım T (2006). Path coefficient analysis of yield and yield components in bread wheat (Triticum aesivum $\mathrm{L}$.) genotypes. Pak J Bot38(2):417-424.

Bhutta WM, Barley T, Ibrahim M (2005). Path-coefficient analysis of some quantitative characters in husked barley. Caderno de Pesquisa Ser Biol 17(1):65-70.

Board JE, Kang MS, Harville BG (1997). Path analyses identify indirect selection criteria for yield of late planted soybean. Crop Sci 37:879-884.

Dofing SM, KnightCW (1994). Yield component compensation in uniculm barley lines. Agron J 86:273-276.

Finne MA, Rognli OA, Schjelderup I (2000). Genetic variation in a norwegian germplasm collection of white clover (Trifolium repens L.): Correlation and path coefficient analyses of agronomic characters. Euphytica 112:57-68.

Garcia del Moral LF, Ramos JM, Garcia del Moral MB, Jimenez-Tejada MP (1991). Ontogenetic approach to grain production in spring barley based on path coefficient analysis. Crop Sci 31:1179-1185.

Grafius JE (1964). A geometry for plant breeding. Crop Sci 4:241-246.

Gravois KA, McNew RW (1993). Genetic relationships among and selection for rice yield and yield components. Crop Sci 33:249-252.

Hamid ZA, Grafius JE (1978). Developmental allometry and its implication to grain yield in barley. Crop Sci 18:83-86.

IlkerE(2006). Relationships between yield and yield components of barley crosses. J Agric Fac of Ege Univ 43(3):1-11.

Khan HA, Shaik M, Mohammad S (1999). Character association and path coefficient analysis of grain yield and yield components in wheat. Crop Research Hisar 17(2):229-233.

Kisana NS, Tahir M, Mujahid MY, Ahmed I (1999). Variability and relationship between morpho-phenological traits and grain yield in winter and facultative barley under stress environments. Pakistan J Biol Sci 2(3):767-771.

Moghaddam M, Ehdaie B, Waines JG (1998). Genetic variation for and interrelationships among agronomic traits in landraces of bread wheat from southwestern Iran. J Genetics Breed 52(1):73-81.

Mohammad S, Fida M, Mohammad T (2002). Path coefficient analysis in wheat. Sarhad J Agric 18(4):383-388.

Narwal NK, Verma PK, Narwal MS (1999). Genetic variability, correlation and path coefficient analysis in bread wheat in two climatic zones of Hayrana. Agric Sci Digest, Karnal 19(2):73-76.

Puri YP, Qualset CO, Williams WA (1982). Evaluation of yield components as selection criteria in barley breeding. Crop Sci 22:927-931.

Sabanci CO (1996). Determination of relations between yield and yield components in common vetch (Vicia sativa L.) by using path analysis. III. Grassland and Forages Congress in Turkey. Erzurum 656-660 p.

Samonte SO, Wilson LT, McClung M (1998). Path analyses of yield and yield-related traits of fifteen diverse rice genotypes. Crop Sci 38:1130-1136.

Samarrai SM, Seyam SM, Mian HR, Dafie AA (1987). Growth periods, harvest index and grain yield relationships in barley. Rachis Barley Wheat Newslett 6(2):21-24.

Sinebo W (2002). Yield relationships of barleys grown in a tropical highland environment. Crop Sci 42:428-437.

Singh MK, Pandey RL, Singh RP (1987). Correlation and path coefficient analysis in barley grown on saline soil. Current Agric 11(1-2):55-58.

Surek H, Korkut KZ, Bilgin O (1998). Correlation and path analysis for yield and yield components in rice in a 8-parent diallel set of crosses. Oryza 35(1):15-18.

Surek H, Beser N (2003). Correlation and path coefficient analysis for some yield-related traits in rice (Oryza sativa L.) under Thrace conditions. Turkish J Agric For 27:77-83.

Turk M, Celik N (2006). Correlation and path coefficient analyses of seed yield components in the sainfoin (Onobrychis sativa L.). J Biol Sci 6(4):758-762.

Turk M, Celik N, Bayram G, Budakli E (2008). Relationships between seed yield and yield components in narbon bean (Vicia narbonensis L.) by path analysis. Bangla J Bot $37(1): 27-32$. 